\title{
The Coordinated Development of Party Construction Work and Campus Atmosphere Construction in Private Colleges and Universities
}

\author{
Wang Hongwu \\ Guangdong University of Science \& Technology,Dongguan 523083,China; \\ $286237918 @ q q . c o m$
}

Keywords: private universities; party building work; campus atmosphere; collaborative development

\begin{abstract}
Strengthening the school spirit, teaching style and style of study in private colleges and universities is an important way for private colleges and universities to improve the quality of education and improve the level of running colleges and universities. Strengthening the party building work in private colleges and universities is a specific requirement to thoroughly implement the spirit of the 19th National Congress of the Party. It is to ensure the private The important measure of the socialist direction of college construction is that only by focusing on campus atmosphere construction and carrying out the tasks of party construction for private colleges and universities can we complete the task of party building on the basis of promoting the development of all kinds of work in colleges and universities in order to make every task of party building in colleges and universities effective.
\end{abstract}

\section{Introduction}

Strengthening the party building work in private colleges and universities is the only way for the party to play a political role and vanguard exemplary role in the development of private colleges and universities. Through the strengthening of party building work in universities, all parties can work together to form a good school atmosphere, and teachers and students can be ideologically strengthened. The education and management of the Party will enhance the concept of Party spirit, promote the fine traditions, and give play to the vanguard and exemplary role of the teacher Party members and student Party members, and promote the formation of good school spirit, teaching style and style of study.

\section{Focus on the construction of "school spirit" and promote party building work}

The school spirit is the school's overall atmosphere. A good school spirit is not only one of the results of education and management, but also has a special role in education and management. It is an invisible spiritual force, a beacon of school development and a valuable spiritual asset. It is also a spiritual pillar on which schools depend. , With strong cohesion, binding force and deterrent force, excellent school ethos has a strong call, infection, assimilation, incentive and normative role. A good school spirit is a necessary condition for school survival and development.

2.1 Use the prestige of the party organization to unite all forces and create a good school spirit.

The construction of school spirit is a systematic project. Only the coordination among various departments and units of the school can bring the scattered forces together into a powerful force and promote the construction of school spirit. In order to form a joint force among the board of directors (board), the dean's office, and the party committee's "troika," in particular the role of the party committee secretary and supervisory commissioner in the entire process and all aspects of guiding and supervising the work of the college, the college should adopt "bidirectional The method of serving the post - the members of the leadership of the party committee has entered the school's decision-making organs and high-level administrative management organizations. If the secretary of the party committee is both a member of the board of directors and a leader of the college. The party committee guides and supervises schools in compliance with laws and regulations, 
participates in decision-making on major school issues, supports school decision-making bodies and deans in exercising their functions and powers, and urges them to administer education and regulate management in accordance with the law.

Party organizations play a political core role. Party committee secretaries participate in the board of directors and dean's office, support the school's policy-making organs and principals in exercising their functions and powers, supervise them to govern and standardize management in accordance with the law, support school reform and development, and help solve outstanding problems that affect the development, stability and stability of schools. Establish a consultation and communication mechanism between party organizations and school decision-making agencies and administrative management agencies.

2.2 Using the exemplary role of party members to strengthen the construction of campus culture and improve the spiritual realm of teachers and students.

College campus culture is a concentrated reflection of the values, ethos and ideal pursuits that have been accumulated in the development process of the school. Through the construction of campus culture, a positive and up-to-date cultural atmosphere can be created, so that teachers and students can enhance their spiritual realm in the imperceptible education guidance.

In the construction of campus culture, the role of party building work in the coordination among relevant departments should be brought into play. The college party committee and various departments can strengthen the party's grass-roots organization's guidance to student organizations and give full play to the positive role of party branches and party groups. Through the party's organizational construction and selection, and the training of leaders in the construction of campus culture, we will select appropriate leaders for the construction of campus culture to improve the quality and level of people's campus culture.

2.3 Grab the group and create a new situation for the work of the trade unions and the Communist Youth League.

The party committee should support the college trade unions to actively explore the road to build trade unions in private colleges and universities. The establishment of trade unions in private colleges and universities can serve as a cohesive force to generate the centripetal force of production. The college trade unions regularly hold teachers' conferences, establish collective labor contracts, and promote public school affairs. The opinions and suggestions of the faculty on the development of the college and the collection of collective wisdom have played an active role in promoting the reform and development of the college.

The college party committee insisted on "building the party building and leading the mission," and supported the college Communist Youth League committee to closely center on the "promoting students' all-round development" and to create a "red flag league organization" and "advanced work" as the carrier, and to innovate the work of the group to advance the mission of the group in an all-round way. The construction has fully exerted the role of the Communist Youth League in uniting youth, educating youth, and serving young people.

\section{Focus on the construction of "teaching style" and strengthen party building work.}

The teaching style is the teacher's demeanor, is the unity of the teacher's virtue and talent, is the core of the teacher's overall quality, and is a concentrated reflection of the teacher's morality, talent, style, accomplishment, and teaching. Teaching style is an important part of school spirit. The party organizations at all levels in universities must learn through education and enable the party members of the teachers to clearly understand the significance of vanguard and exemplary roles played by party members and teachers in colleges and universities. Through learning, the party members of teachers have a strong sense of responsibility and a sense of mission to maintain the advanced qualities of party members. Party members teachers. Become an outstanding member of the party, a leader in the teacher. Specific should do the following:

3.1 Strengthen the construction of teaching and administrative party organizations.

Refine the organizational form. Set up party organizations in the form of teaching and research offices and offices to form a party organization system that is integrated with administration, 
teaching, scientific research, and administrative management. It is conducive to the party members of the teaching staff to carry out party building activities in their own work and to play a vanguard exemplary role for party members, but also to facilitate strong Education and Management of Teachers' Party Members. Improve the content and form of the Party's organization activities for the teaching staff. Organize and organize around the development and teaching of the college. Organize and organize excellent teaching and scientific research, good teachers and models, and promote the construction of the teaching team to effectively enhance the effectiveness of the Party's activities.

3.2 Strengthen the construction of teachers' party members.

Do a good job of development. Party organizations at all levels must strengthen the guidance of outstanding young teachers and the backbone of teaching and scientific research. They should implement methods for the party members to contact young teachers and the backbone of teaching and scientific research. They should actively make friends with them to attract them to participate in party lessons and organize their lives. The outstanding members of the teachers are attracted to the party and lay a good foundation for strengthening the ranks of the party members. It is necessary to do its utmost to provide opportunities for outstanding young teachers and the professional development of teaching and scientific research, create conditions, build a platform, create an environment, guide outstanding young teachers and teaching and scientific research cadres to delve into teaching and scientific research business, and become leaders of professional professionals and subjects in this field. character. Concerned about the growth of young teachers, to create more room for their growth, provide more opportunities for development, so that the majority of young teachers can truly experience the care of the party organizations, so that they consciously demand progress and take the initiative to move closer to the party organizations.

Strengthen the education of teachers' party members. Improve the ideological and theoretical qualities of teachers' party members. Guide the majority of teachers' party members, especially outstanding young teacher party members, and the backbone of teaching and scientific research, so that the majority of teachers of party members can establish the awareness of the party and the sense of party members, be loyal to the education of the party, and give better play to their demonstration, promotion, and education for teachers and students. . Strengthen teachers' professional ethics and professionalism education, help them to develop conscious and pragmatic and rigorous self-discipline of academic attitudes, and consciously abide by academic ethics. Through the party committee's call, the teachers and students of the entire hospital were selected to publicize a group of teachers' virtues and advanced models of teaching and educating people, so that the majority of teachers learned examples, rushed to the goal, doing a good job, and formed a good teacher morality and guidance.

\section{Focus on the "learning style" and strengthen party building work}

Learning style refers to students' behavioral norms and collective performance of ideology and morality. It is the spiritual outlook displayed by students in the learning process. We must make full use of the party's political and organizational advantages, innovate the work of party building among college students, innovate the work of ideological and political education for college students, and vigorously promote the construction of college study style to promote the overall development of college students.

4.1 Actively innovate the construction of student party organizations, so that it becomes the core of the organization that leads the healthy growth of college students.

In keeping with the construction of college students' party groups in classes and grades, they are adapting to new changes in the way students learn and live, innovate in party organization settings, and explore the effectiveness of building student party organizations in student apartments, student clubs, practice bases, and online. Form, to form a more scientific and rigorous, practical and effective party organization system. According to the fact that undergraduates have fewer courses, more internships, and scattered activities before graduating from college, they have extended the education and management of the party organizations and explored new ways to strengthen party organization. Aiming at the new circumstances in which college graduates from some colleges and 
universities are involved in the detention of their party members, we must study how to implement effective education management and organizational relationship transfer methods to ensure that each party member participates in organizational activities and plays a part-time role.

4.2 Actively improve the content and methods of student ideological and political education.

Effectively enhance the pertinence and effectiveness of ideological and political education, mobilize the enthusiasm and initiative of college students, and continue to increase the pertinence and effectiveness of ideological and political education. Focusing on the hot spots and focus of college students' attention, we have actively expanded educational channels and conducted in-depth social practices to enrich the themes and contents of ideological and political education for college students, so that ideological and political education is more closely related to students' ideological realities. The problems existing in the ideological and political affairs of college students and the normative norms of behavior are not to adopt a method of chasing and intercepting, but to focus on the guidance, to strengthen the guidance, to realize reason, to move with emotion, to moisten things. Improve the overall quality of college students to expand the certification system, comprehensively increase the enthusiasm of students to participate in all types of activities, improve the overall quality of students, and promote the overall development of students; improve assessment methods, and effectively implement teaching, education, service, education, Efforts are made to educate all members, cultivate people in an all-round way, and educate people throughout the entire process.

4.3 Give play to the vanguard and exemplary role of student party members in the construction of study style.

The ultimate criterion for measuring the work of party building in colleges and universities is to see the role played by party organizations and party members. It is to see whether it is conducive to promoting the development of all kinds of work and whether it is conducive to promoting the all-round development of students. As the advanced elements and backbone of the students, student party members are the model and model for the majority of students. They are the most closely linked ties and bridges between the school party organizations and young students. In the construction of study style in colleges and universities, we should attach great importance to and strengthen the self-construction of college student party members and play an irreplaceable vanguard and exemplary role. Party members of students should follow the "Articles of the Chinese Communist Party Constitution", abide by the rules and regulations of the school, strengthen political learning, improve political theory and professional theoretical level, and play an active role model, role model, and leading role in learning, work, and life. The good image of student party members has made positive contributions to the construction of study style.

\section{References}

[1] Guo Xiaoping. The relationship between university generational talent and college school ethos [J]. Journal of Yulin University.2011,21(2):110-112.

[2] Qi Weiping 2l. On the Inner Unity of the Dual Role of Party Member Teachers in Colleges and Universities [J]. School party building and ideological education. 2004(9):2325.

[3] Liu Weixing. Status Quo Analysis and Countermeasures of College Teachers' Teaching and Educating People [J]. Journal of Chongqing Three Gorges University, 2002(6):7679. 